\title{
Exploring the motifs of death and immortality
}

\author{
Oscar M. Maina
}

\begin{abstract}
The quest for immortality is a universal undertaking. Human beings have always felt threatened by the eventuality of death, inculcating in them a fear so great that all possible strategies are engaged in the search for an avenue that would prepare them for this eventuality. A careful exploration of human activities surrounding the issues of death and immortality reveals an obsession with the expression of the possibility of defeating death through the artistic act.
\end{abstract}

Art functions as the arena where human beings can mock, jeer, and repudiate mortality. Indeed, death is a central conundrum in philosophical, literary and even religious arguments that focus on human identity and reality. The usefulness of literature in exposing human fears, aspirations and desires is emphasized as literature functions as the meeting point where all manner of philosophies are presented and debated. In examining how the motifs of death and immortality are represented in the artistic act, it is imperative that this article draws from a wide range of genres.

Apparently, both oral and written forms of human expression, as well as metaphysical, fantastic and mythic representations of the cultural text have been taken into consideration. The revelation is that we rely on art to express even our deepest fears, and we reciprocate by giving art an immortal status. This results in an interdependence that combines to defeat the abrasiveness of mortality. Also, this symbiotic relationship accords the creative act a pivotal role for it gives death a form and a face, making it easier for us to deal with it and assume a privileged psychological standpoint.

\section{Introduction}

The fear of death is perhaps the most universal fear that has engaged human inquisitiveness over the centuries. But what makes death such a fearsome phenomenon? When we are born, we acquire an identity which forces us to act, to think, and to sustain (throughout our lifetime) a unique consciousness. This lifetime engagement is what is irrevocably lost at the moment of death. Given a chance, we would all want to reverse the rules so that we can forestall our appointment with death. It is in the quest for this slim chance that humans have engaged every source of knowledge that promises an answer. These possibilities range from religion to philosophy and most importantly the engagement of art in this quest. Art, through its creative power provides us with an avenue through which we can create explanations that would make life less of a futile engagement.

This article explores how human beings utilize art as a resource as they grapple with issues that go beyond the realm of their immediate understanding. In fact, art and literature have always served as the most concrete means of transforming abstract human experience into tangible forms. These abstract experiences in some cases 
only exist in our imagination or in other cases, only as part of our rich instinctive consciousness. Informed by this fact, we may argue that our response to death and our quest for immortality is an essential part of a universal consciousness and identity. The high premium that we attach to our identity presupposes a desire to retain that identity beyond the point of death. Unfortunately, we have no human resource that may enlighten us, with certainty, on what becomes of us after our final loss of consciousness. However, our creative instincts enable us to create characters that succeed where we have failed. In Freudian terms, this is akin to using art as a tool that mediates between subjective meanings and objective external realities.

What gives force and validity to this representational tool is our shared symbolic culture. As humans using language, we assign meaning to various experiences through not only our ordinary communicative acts, but also through our artistic recreation of these experiences. In this undertaking, we tend to create binaries that help us define our fears, aspirations, and uncertainties. In the context of our current discussion, we may examine the life/death and immortality/mortality binaries. In Derridian terms, we would necessarily privilege the binary that comes first in the set. The conclusion here is that in addressing the motifs of death and immortality, we tend to privilege life even after death, and thus immortality manifests as a significant concern for this creative act.

\section{Mytho-poetics and the Human Society}

From the foregoing, we may explore myths as that genre of literature through which human societies, orate or literate, admit and attempt to explain away issues that go beyond their understanding. Such matters include life, death, and immortality. It is therefore imperative that any attempt to explore these themes and motifs must consider mythical and socio-philosophical view points. It is to this end that part of the paper will be devoted to the exploration of the African myths on the origin of death, the biblical understanding of the reason for death, the philosophical debates, and eventually on how these debates are explored, expressed, and even countered through the literary act.

Thomas Wharton (2001), in his novel Salamander wrote the following words: "Over the years I've come to understand that a book itself desires to be. Dream a book, no matter how outlandish or unlikely, and that book will find a way to exist, even if it must wait a thousand years" (p.167-8). When Wharton wrote these words, he was adducing evidence to the fact that there is a link between artistic and human quest for immortality. More importantly, Wharton points out the universality of our obsession with art and immortality. Is it that artists, in a bid to defy mortality, use art to express their own idiosyncratic fear of death? If this were true, the quest for immortality, as a theme and motif, preponderate works of art. This obsession with immortality is the single most important drive that gives Thomas Wharton's Salamander its momentum. Obsession may be a good thing for as the story illustrates, it may be a reservoir for inspiration, innovation and discovery. In this narrative, Wharton defies the conventional modes of mimesis and reaches out to seek the resources of surrealism; a creative method that enhances textual resonance between subjective meanings and external realities. In Salamander, Wharton depicts the story 
of humans engaged in the writing of an immortal book, and in essence, a search for human and artistic immortality.

Salamander is a story that owes its primary force to death and destruction. The year is 1717. The Christian armies under Prince Eugene of Savoy are fighting the Ottoman Turks. Count Konstantin, an aide-de-camp to Eugene, has his only son under his command. The son is young, inexperienced, and, "under the intoxication of his body's youth and animal vigour" (p.13). As fate would have it, the son dies while undertaking his first commission. Konstantin resigns and reverts to his earlier, suppressed obsessions: cryptograms, mathematical oddities, philosophical conundrums and optical illusions. Underneath these obsessions lie an extreme inquisitiveness and a quest for order in times of chaos. This acquaintance with Wharton's text provides us with a vista through which we can analyze two important issues: the genesis of human fear of mortality, and how we, the mortals, attempt to explain and transcend the chaotic uncertainty that characterize our temporal world by engaging the creative enterprise.

As a trait with all humans, Wharton argues, we seek answers to two primary questions: why God, a perfect being, created an imperfect temporal world (a mortal world), and why the human mind, a composite engine of messy animal imperfection has in itself the genesis of a clockwork order of chaos. But chaos and mortality are products of human incorrigibility and disobedience. God, in His infinite wisdom, created man an immortal being who didn't have to sweat for his upkeep, and whose residence was a perfect paradise where the aspect of time was alien. After committing the mortal sin, man was dethroned. Mortality was meted out on man as punishment, and the aspects of time and ageing were clipped in. That is, the privileges of immortality and the ever benevolent paradise were revoked.

However, human beings continue to display an overwhelming nostalgia for their immortal status. Artistic expression is the main arena where this pining for better days is played out. Consciousness, the awareness of the self, is inextricable from our desire to always be. Even though we know and experience death in every turn, death in every turn (paradoxically) reinforces our belief in immortality. Jacques Maritain in The Immortality of Man explores the two human Persons of the human being and rightly points out that we are hostage to two types of aspirations: the connatural and the trans-natural.

Connatural aspirations, according to Maritainian distinction, focus on the nature of the human personality, while the trans-natural focuses on "the transcendental perfection of personality" (p.7). What aspirations are responsible for our resistance of death? Maritain asserts that connatural aspirations (which include immortality) are not prone to deception, for they touch the very soul of the human being. Paradoxically however, immortality is also a part of the entire human personality and thus a trans-natural aspiration open to deception. This is where it gets interesting. Our quest for immortality is so resilient such that even though death constantly reminds us of its certainty, the deceptive trans-natural aspiration for immortality by a principle secret to nature alone, remains deeply entrenched in us. It is this resilient part of the human soul that finds expression through the artistic act. Art is therefore 
the most appropriate way of announcing our defiance of mortality. But before this tool becomes functional, we must negate and scatter external realities that remind us of our limitations.

In the realm of a metaphysical, imaginative, and fantastic art, human beings grapple with the limitations of their human form. It is in this endeavor that communities the world over create and re-create legendary and epic heroes whose architecture is replete with superhuman qualities. We, the participants in this artistic delusion, appreciate and savor their conquests against the limitations of the human form, as they assign death and annihilation (presumably on our behalf) to our real and perceived enemies. In retrospect, this annihilation furthers our chances by diminishing competition to our continued existence. This fact is rendered true by the embellished language cultures employ in creating, recreating, rendering, and immortalizing legendary and epic heroes. The legend and the epic are foundations in our quest for a sense of identity, and as in the myth of origin, they reinforce our belief in an initial immortal status. Informed by this belief, we are reluctant to accept blame on the causes of mortality, and instead we feverishly hunt for excuses that may exonerate us from any wrong-doing by creating myths that abet our subjective confrontation of objective reality.

As opposed to the epics and legends, myths serve an ontological purpose that go beyond explaining the immediate social and physical environment. They account for human fears and desires, particularly the fear of death and definite mortality. All the prohibitions that are encountered in these myths betray an urgent desire for self-preservation and eventual triumph over time.

In a Luo myth on the origin of death, the chameleon is given a fatty piece of meat to take to the moon. Out of gluttony, the chameleon eats part of the meat and soils the rest. When taken to the moon, the offering is rejected and mortality meted out on humans as punishment. In Oral Literature: A senior Course, Akivaga, Gachanja, and Nandwa posit that myths draw their power from the fact that they are understood as facts, and for the reason that "myths explain how such calamities as death and the need for man to work came to earth" (p. 91). Does this assertion ring any bells? In the biblical account of Creation, Adam and Eve are punished with death and work for their disobedience. This fact (apart from explaining why we must expend energy in search of sustenance) gives credence to the universal fact that art is a useful tool that helps us alienate our displeasure, fears, aspirations, desires, and many other abrasions to the human spirit.

Amongst the Kalenjins, for instance, death is attributed to the folly of a hunter who inadvertently kills Thunder's son. Thunder, out of anger, sends heavy rains and eternal sleep as a way of punishing the community. What these and other myths precipitate is the fact that human beings believe that they were created immortal, but they attracted the wrath of the gods who imposed mortality as, according to Ciarunji Chesaina, "an irreversible decree of the supernatural thus forcing human beings to accept it as a fait accompli" (p. 41). 
The lament over human dethronement and the imposition of mortality pervades human encounter with art and the scriptures. According to evangelical gospel, the human body is endowed with a soul that resides in it. At death, the body dies but the soul assumes an immortal status. This, however, is a subject of debate. Would it be necessary for God to offer immortality to an eternal soul? John 3. 16 states, " for God so loved the world so much that he gave his only Son, so that everyone who believes in him may not die but have eternal life" (Good News Bible). Immortality, from the foregoing, is not innate but subject to believing in Christ as atonement for human sins and initial disobedience. This controversy, as in the myths that seek to explain the origin of death, crystallizes human desire to endow ourselves with immortality, while seeking for reasons that excuse definite mortality. We want to see ourselves as created immortal and with the ability to defy death, even in death.

In the Great Family of Man Roland Barthes explores the myths of the human condition, and continues to argue that issues of birth, work and death are universal facts. Regarding death, Barthes queries: "must we really celebrate its essence ... and thus risk forgetting that there is still so much we can do to fight it?" (p. 13).The fight against death that Barthes advocates for may go beyond medical and scientific technology to include defying the finality of death. Through art, the cruelty of death may be confronted, defied, and eventually broken down to manageable realities.

\section{Literature and Socio-Philosophical Reflections}

In Margaret Ogola's Place of Destiny for instance, Mwanghera, Amor's husband laments thus after his wife's death: "to live is to be in strife with time. Time comes and we die and return to the fragmented molecular state. So one hopes in the spiritsingular, non-fragmentable, life-giving yet now departed and unreachable" (2005, p.154). Still referring to Amor's death, Igana Mago reflects: "Death is an absence, the departure of a force- a great force that has moved the person to live, to act, to love, to dream dreams" (p. 150). It is explicit that these characters are attempting a philosophical understanding of life and death, and how the immortal status is or may be realized. The force that Mago refers to is what in other quarters is known as the identity or the consciousness of a person. In the words of Richard Sorabji, our fear of death or physical annihilation arises out of the fear "of losing ... selfhood" (p. 337). Selfhood in this context may either be physical or in the form of a disembodied survival. The two understandings of selfhood also represent the two forms which immortality is perceived to take: physical resurrection of the body, and the survival of the soul.

Does death afflict the body or does it also afflict the mind? Peabody, the doctor character in William Faulkner's As I Lay Dying, is philosophical in his analysis of what death is. As opposed to his childhood conviction that death was a bodily phenomenon, he is now convinced that "it is a function of the mind and that of the minds of those who suffer the bereavement" (1987, p. 39). According to Peabody's argument, social death preempts the physical absence. In Faulkner's narrative, the death of Addie Brunden throws the family in a furry of activities in their attempt to fulfill her burial wishes. This feverish preoccupation with the death-bed wishes is neatly tied to the concept of immortality for death is "in reality ... no more than a 
single tenant or family moving out of tenement" (39), and we may therefore assume that the dead individual moves into another neighborhood; into immortality.

Virtually every society embraces and perpetuates the idea of life after death. In the pre-colonial African societies, death is a transformation and ascendancy to a higher socio-spiritual ranking. Upon death, one becomes an ancestor or a spirit. This is in contrast to the modern anxieties occasioned by the fear of cessation of existence; the fear of death as an absolute end. The after-life plays a sociospiritual role in enhancing the continuity of a society as stipulated in the myths of these societies, and in their art. With the rise of postcolonial writing, creative writers seek to dig back into the historical past of their societies and confront the world with historical and cultural realities that inform the identity of the colonized. Immortality, as a motif, has been canonized as part and parcel of the African cosmology. In fact, it is a major conundrum in postcolonial literary discourse that aims at denouncing Western evangelization and abnegation of "heathen" precolonial African worship.

Christopher Okigbo, Chinua Achebe and Wole Soyinka share in their portrayal of the cyclic nature of life. Death is a crossroads where immortality and continuity are synthesized. In Okigbo's Labyrinths, this cycle is presented thus: "the man embodies the child/ the child embodies the man" (1962, p. 64). This embodiment may also point at the idea of reincarnation where the dead are born back into the society. In many African communities, the act of naming newborns serves the purpose of preserving the memory (and the identity) of departed members of the society. Amongst the Luhyia of Western Kenya, it is believed that a child embodies the conscience of the person it is named after, and if the parents fail to name the child accordingly, its incessant cries will force the parents to appease the departed by naming the child after them.

However, this form of reincarnation and rebirth is ideally different from the Abiku and the Ogbanje in that the Ogbanje does not live to adulthood. The idea of rebirth as represented by the Abiku and the Ogbanje, "one of those wicked children who, when they died, entered their mothers' wombs to be born again" (Achebe p. 54) brings sorrow and suffering to the living. This cycle of death could only be broken if the Ogbanje's iyi-uwa 'placenta' was found and exhumed. Reincarnation manifests in that in an effort to elude the Ogbanje's teasing cycles, medicinemen disfigured and mutilated their corpses to frighten them, but the most incorrigible returned with the evidence of this mutilation. The Ogbanje amplifies the cyclic nature of life, and perhaps best illustrates the African philosophy of death and immortality; the living, the dead, the living-dead, and the ancestors are part and parcel of the society.

Amongst the Igbo, as presented in Chinua Achebe's Arrow of God, the dead demand a second burial. Ogbuefi Amalu, "who had already stood too long in the rain and sun" must be ushered into the shelter of the shrine through an elaborate and extravagant ceremony. Apparently, one took his previous status with him, and the rich and titled demanded an immediate admission into ancestry, while "a 
poor man might wander outside for years while his kinsmen scraped their meager resources together [this being] his penalty for lack of success in his life (1964, p. 221). Immortality is in this way perceived as inherent in social understanding and existence. Death is therefore not an absence but a presence, though this comes with the transformation that is played enacted through death.

But as in Ben Okri's The Famished Road, the Abiku child is not always evil. Azaro, an Abiku child pities the mother and decides to stay, and thus retains the ambivalence of spiritual and the human nature. In Okri's postmodern novel, there is a collocation of African traditional and Christian discourse, primarily exemplified in Azaro's allusion to Lazarus in the Bible. The biblical version of creation has been localized in the following manner:

In the beginning there was a river. The river became a road and the road branched out into the world. And because the road was once a river, it was always hungry. In that land of beginnings spirits mingled with the unborn. We could assume numerous forms.... And we sorrowed much because there were always those amongst us who had just returned from the world Living. (1991, p. 3)

Azaro's duality is functional in not only decoding the "world of riddles" (388), but also in apprehending Okri's presentation of the socio-spiritual, as in the following part of the narrative:

[Human beings] had been living for eternity as faces on the great tree. They got tired of eternity. They were the ones that the sun didn't melt into precious water. They became beings, people in masks. One day their prophet told them that there were worlds and worlds of people high up ... and said they should build a great road so that they could visit the spirits. (p. 329)

It is apparent that Okri utilizes the myth of the Abiku child (Azaro) to explore the place of African religious and mythological beliefs in the presence of overwhelming Christian influence. The express result is ambivalent synthesis, where African myths and Christian doctrines blend. From the this blending, human beings are not dethroned by their creator who imposes the curse of mortality, rather death is a result of the sojourn into the spirit world through the road prescribed by their prophet. This is the road that leads to death; the site of transformation from the humanly mask to the original spiritual form. Okri's text traces the origin of death to the human curse: curiosity and disobedience.

The versatility of poetry as a means of capturing human experience allows it to present the different literary approaches to the theme and motif of immortality. There is on one hand a stoic acceptance of death, and a more resistant approach to death on the other. Let us for instance sample Dylan Thomas' "Do not go gentle into that good night":

Do not go gentle into that good night, old age should burn and rave at close of day; 
rage, rage against the dying of the light.

The persona in the poem cites the deeds of the wise, the grave, the wild and the good men, and urges them not to go gentle into that good night. The clincher of the poem is the persona's desire for either a curse or a blessing from his father. It is worth noting that this poem is said to have been triggered by Thomas' dying father. Thomas' inspiration aside, it is important to observe that the poem underscores the thin line that separates life and death. All our actions; good or bad, noble or not, end at death. Nevertheless, death is to be confronted, not accepted without putting up a fight.

Contrary to Thomas' silence on what happens after death, metaphysical poets engage the religious philosophies in search for answers. Henry Vaughan in "They are all Gone into the World of Light," is convinced that death precedes eternity:

Dear, beauteous death! The jewel of the just,

Shining nowhere, but in the dark

What mysteries do lie beyond thy dust;

Could man outlook that mark! (p. 95)

Vaughan's presentation of immortality is informed by religious imperatives. Immortality is the preserve and a reward of the just. These are the "stars" who even when confined into a tomb, their "captive flames must needs burn there". The persona yearns for true liberty; liberty that is only possible if and when the spirit is separated from the body; the essence of slavery. The human body is limited in perspective. There are doubts and mists that cloud his understanding, and if God can't clear them, He should "remove [him] hence unto that hill/ where [he] shall need no glass." The hill is symbolic of heaven where the persona needs no telescope for he will have assumed a spiritual form, which is resumed after death.

A similar trajectory is captured in John Donne's "A Valediction: Forbidding Mourning." Death is not to be mourned but to be confronted with ultimate stoicism:

So let us melt, and make no noise,

No tear-floods, nor sigh-tempest move,

Twere profanation of our joys

To tell the laity of our love. (p. 70)

Death is once again presented as the site where the interchange between body and soul is operationalized. But the human form evokes its own nostalgia; careless eyes, lips, and hands will be missed. However, these are sublunary (beneath the moon) and subject to decay; to be discarded with the body at death. For the loved ones left behind, comfort arises out of the realization that the departed are like one foot which has moved ahead. In this way, Donne concretizes the interchange between body and spirit; the foot left behind should not pine for the departed, for "thy firmness makes my circle just/ And makes me end, where I began." Death, as portrayed by Donne is 
an accomplishment that facilitates immortality through the circle and cycle of birth, death, and rebirth.

Stoicism does not limit itself to Donne's metaphysical attitude towards death. When living becomes more of an inconvenience, death may be solicited. In Greek tragedy, the imminent and irreparable death of the tragic hero invites a swift death as an appeasement for the brute fury of malevolent gods. The hero, who fatal destiny must confront, is apparently in need of an end to his suffering. There is a vindictive and even masochist perception of death. This death must be invited as does Cleopatra in Garnier's Marc Antoine:

Ah death, $\mathrm{O}$ gentle death, sole remedy

For souls pinioned in captivity,

Why let your rights be flouted thus?

Did we offend thee, gentle, gentle, death?

Why not draw near, $\mathrm{O}$ tardy fate? (qtd in Steiner p. 25).

Living is akin to captivity and death the only escape route. Death is thus not a phenomenon to be abhorred, but a prescription which alleviates our earthly suffering. The cathartic effect of tragedy is actualized after the death of the hero, and as Raymond Williams observes, "life is regularly read back from the fact of death" (56). This means that the death of the hero (and in fact any death) forces us to grapple with the interpretation of death and its aftermath. But unlike the "deserved" death of the tragic hero, cultures world over have always attempted to privilege life over death, by particularly extending their existence beyond death into an immortal status. Death and mortality become primary questions that force us to create a philosophy that affirms life and self preservation by negating the omnipotence of death.

\section{Customized Art and the Inorganic Memory}

For instance, in the socio-economic and metaphysical politics of the ancient Egypt, the aspect of immortality is taken to a complicated level altogether. Perhaps due to the precarious, delicate ecological balance that dictated life in Egypt, the gods manifested in every sphere of life. To reach out to the gods, ancient Egyptians depended on the intercessory power of the Pharaoh. He represented a dual personality: half human, half god. The Pharaoh was hence beyond human, and consequently beyond mortality. What happened after a Pharaoh's death? It was inconceivable that a demigod could die, and his death was interpreted to symbolize a transformation into the spiritual. He became part and parcel of the complex world of Egyptian gods and goddesses, and his physical body had to be immortalized through mummification, an exercise which was overseen by Anubis, god of mummification.

Mummification did not only involve coating the body of the dead with resin, but talismans and amulets were also given to the dead, apparently to help them overcome any inhibitions in their journey to the spiritual. The process of bodily preservation entailed removing internal organs although the heart, which was believed to be home to the individual's soul and the embodiment of one's personality, was left intact. 
Admission to eternity was not automatic. The dead had to go through the hall of judgment and those whose hearts were lighter than feather were handed over to the Osiris, god of the afterlife.

Another interesting fact about the Egyptian perception of immortality is their belief in the power of art. It was customary to bury the dead with customized songs, texts, and pictures engraved in papyrus. This, it was believed, eased their journey through the land of the dead. Art in this case was given a potent power equal to that of a talisman, but which also held the memory of life on earth. It is worth noting that on the event of death, the brain was removed and discarded. It is possible to argue that these customized artistic texts were meant to fill the void of the lost memory, as well as means of extending one's identity beyond the point of death.

But the Egyptian attempt at the actualization of immortality points at deeper philosophical meanings. Human intelligence thrives on organic memory; the recollection of lived experiences. However, this alone cannot fully support the activities of the human brain for at certain times imagination comes in to supplement this deficient memory. Art, the act of creating imaginatively, serves this purpose. In regard to immortality, art enables humans retrieve their imagination of a phenomenon that is beyond their objective memory. This means that even though it may lack in certitude, subjective immortality is vital in complementing our apprehension of a fact that is beyond our objective, lived experience. Interestingly, the Egyptians' removal of the brain of the dead and in its place giving the dead customized works of art symbolically marked the exchange between the perishable human memory and the more enduring imperishable memory. This fact celebrates the immortality of art, and also reaffirms our reliance on it for the preservation of our perishable memories that include our consciousness and our identity.

But how sure are we that art is imperishable? William Shakespeare in Sonnet 55 celebrates the immortality of art:

The living record of your memory

'Gainst death and all-oblivious enmity

Shall you pace forth: your praise shall still find room

Even in the eyes of all posterity

That wear this world out to the ending doom.

This sonnet illustrates that art has the potency to outlive the adversity of time and other destructive natural and human activities. Art is more enduring than the weak, transitory human existence. Even in the pre-colonial African society, art was the main tool of socio-philosophical propriety. All the traditions, ethics, philosophies and cultural artifacts of the society were, and still are embedded in art. 


\section{Conclusion}

Art in general, and Literature in particular, is therefore a collective text that is not only timeless, but owned by each and every successive human generation. With our advanced technology, we stand a better chance of ensuring the continuity of this symbiotic dependence of artistic and human quest for immortality. This may explain our obsession with permanent records. We simply are responding to the instinct to preserve everything so that it will outlive us. We in this way abet the immortality of art, and art reciprocates by playing a therapeutic role especially when death confronts us, while at the same time ensuring that death does not take away everything we have had.

\section{References}

Achebe, C. (1964). Arrow of God (2 ${ }^{\text {nd }}$ ed.). Nairobi: East African Educational Publishers.

Barthes, R. (1957). The great family of man. Mythologies.A critical and Cultural Theory Reader. ( $2^{\text {nd }}$ ed.). New York: Open University Press.

Bukenya, A., Gachanja, M., \& Nandwa, J. (1997). Oral literature: A senior course. Nairobi: Longhorn.

Chesaina, C. (1997). Oral literature of the Embu and Mbeere. Nairobi: East African Educational publishers.

Faulkner, W. (1987). As I lay dying (2 ${ }^{\text {nd }}$ ed.). New York: Vintage.

Maritain, J. (1941). The immortality of man. The review of politics, 3(4), 411-427. Retrieved July 3, 2008, from Jstor.

Ogola, M. A. (2005). Place of destiny. Nairobi: Pauline Publications Africa.

Okigbo, C. (1982). Labyrinths. London: Heinemann

Okri, B. The famished road. London: 1991.

Shakespeare, W. Sonnet 55 in Norton anthology of poetry.(3 ${ }^{\text {rd }}$ ed.). New York: W.W. Norton.

Sorabji, R. (2006). Self: Ancient and modern insights about individuality, life, and death. New York: Oxford.

Soyinka, W. (1981). “Season” in P. Robins, \& R. A. Hargreaves (Eds.). A poetry course. Nairobi: E.A.E.P.

Steiner, G. (1961). The death of tragedy. London: Faber and Faber.

Thomas, D. 2006, July 12). Wikipedia.org. [On-line]. Retrieved August 22, 2008 from http://www.wikipedia.org/wiki/Dylan

Wharton, T. (2001). Salamander. Toronto: McClelland \& Stewart.

Willmott, R. (2002). Metaphysical poetry. London: Cambridge. 